\title{
$\mathrm{Cu}-15$ mass \% Cr 複相合金圧延材における 引張特性の異方性*1
}

\author{
熊井真次 1 今井達也 ${ }^{1, * 2}$ 若菜剛 介 $^{1, * 3}$ 加藤雅治 ${ }^{2}$ 佐藤彰一1
}

\author{
1東京工業大学大学院総合理工学研究科材料物理科学専攻 \\ 2東京工業大学大学院総合理工学研究科物質科学創造専攻
}

J. Japan Inst. Metals, Vol. 67, No. 6 (2003), pp. 315-323

(C) 2003 The Japan Institute of Metals

\section{Anisotropy in Tensile Properties of Cold Rolled Cu-15 mass\% Cr Composites}

\author{
Shinji Kumai ${ }^{1}$, Tatsuya Imai ${ }^{1, * 2}$, Gosuke Wakana ${ }^{1, * 3}$, Masaharu Kato ${ }^{2}$ and Akikazu Sato ${ }^{1}$ \\ ${ }^{1}$ Department of Materials Science and Engineering, Tokyo Institute of Technology, Yokohama 226-8502 \\ ${ }^{2}$ Department of Innovative and Engineered Materials, Tokyo Institute of Technology, Yokohama 226-8502
}

\begin{abstract}
A heavily cold rolled sheet of the $\mathrm{Cu}-15$ mass $\% \mathrm{Cr}$ alloy exhibited "in situ composite microstructure" including fine elongated $\mathrm{Cr}$ fibers in the $\mathrm{Cu}$ matrix parallel to the rolling direction. Difference in tensile properties was examined from the longitudinal $\left(\theta=0^{\circ}\right)$ to transverse $\left(\theta=90^{\circ}\right)$ directions of the cold-rolled sheet in order to characterize the tensile property anisotropy. Effects of annealing treatments were also investigated on the tensile properties and the tensile fracture surface morphology. The annealing treatments resulted in decreased proof stress and UTS, and increased elongation. Orientation dependence of the UTS from $0^{\circ}$ to $90^{\circ}$ exhibited $\mathrm{V}$-shape manner with the minimum value at $45^{\circ}$, that was about $75 \%$ of that of $0^{\circ}$ direction. Increase in annealing temperature lifted up the depth of the valley, and the $45^{\circ}$ UTS of the $1173 \mathrm{~K}$ annealed sheet was $90 \%$ of that of $0^{\circ}$ direction. Tsai-Hill equation, which predicted the orientation dependence of failure strength in off-axis tests on unidirectional laminae, fitted well to the present experimental results. The present composites showed small anisotropy both for the tensile properties and electric conductivity in spite of the regularly aligned $\mathrm{Cr}$ fibers along the rolling direction. Annealing treatments brought about further reduction in tensile property anisotropy.
\end{abstract}

(Received February 10, 2003; Accepted April 1, 2003)

Keywords: copper, chromium, in situ composite, rolled sheet, tensile properties, anisotropy, fractography

\section{1. 緒言}

純銅および銅合金は，銀についで高い電気伝導性(以下， 導電率と呼ぶ) と優れた展伸性, 耐食性をもつため電線や IC リードフレームに代表される電気・電子機器用材料として広 く用いられている. 近年は特に強磁場発生用マグネットやト ロリー線材用として，また各種電子デバイスの小型化・薄肉 化のため, 強度と電気伝導性を兼ね備えた材料の需要が高ま っている. しかし銅合金の場合，加工(ひずみ硬化)や合金元 素の添加 (固溶強化)によって強度の向上を図ると導電率は急 激に低下してしまう。そこで一般には高導電率を維持しなが ら高強度を得るためには析出強化が利用され, 例えば 1 mass \%以下の Be を含む合金で導電率 $50 \%$ IACS （International Annealed Copper Standard, 焼鈍した純銅の導電率を $100 \%$ とした場合の比率), 引張強さ $800 \mathrm{MPa}$ をもつ $\mathrm{Cu}-\mathrm{Be}$

\footnotetext{
*1 2001 年 9 月 24 日日本金属学会秋期大会に打いて発表

*2 東京工業大学大学院生, 現在: 川崎重工侏 (Graduate Student, Tokyo Institute of Technology, Present address: Kawasaki Heavy Industries, Ltd.)

*3 東京工業大学大学院生 (Graduate Student, Tokyo Institute of Technology)
}

合金が実用化されている1).

これに加え, 最近では, 銅に固溶しにくい元素を数 mass \%以上添加し，いわゆる二相分離型の複相合金にする ことで高導電率を維持しつつ, 高強度化を達成する方法が注 目されている ${ }^{1-9)}$. 安達らは $\mathrm{Cu}$ と $\mathrm{Cr}$ を融点以上で溶解, 均 一合金融液にした後の凝固過程で $\mathrm{Cu}$ マトリックス中に $\mathrm{Cr}$ 相を第二相として晶出させた二相分離合金を鋳塊とし，その 後の熱間加工や冷間加工により $\mathrm{Cu}$ マトリックス中にファイ バー状の Cr 相を均一分散させた複相材料 (in situ composite)を開発している. 冷間線引きによって作製した $\mathrm{Cu}-15$ mass \% Cr 複相合金線材の熱処理材では 70\% IACS を超える 導電率, $900 \mathrm{MPa}$ を超える引張強さが得られており2,3), 現 在は導電率 $\geqq 80 \% \mathrm{IACS}$, 引張強さ $\geqq 1000 \mathrm{MPa}$ を目標に第 三元素を添加した合金の開発が進められている4-6,8,9).

$\mathrm{Cu}-\mathrm{Cr}$ 複相合金の組織や力学的性質に関しては, 冷間加 工時の $\mathrm{Cr}$ 相の形状や集合組織, $\mathrm{Cu}$ 母相と $\mathrm{Cr}$ 相界面での剥 離の有無に着目した観察, 引張強さと $\mathrm{Cr}$ 相間隔との関係等 が調べられている2,3,7,9).

これらの研究の多くは線材を対象に行われているが, 三原 らは本合金の薄板材としての可能性に着目し, 製造プロセス ならびに作製された $\mathrm{Cu}-15$ mass $\% \mathrm{Cr}$ 複相合金圧延材の基本 
特性について調査している，その結果，圧延材では第 2 相が 圧延方向に配向しているにもかかわらず，力学的特性や熱膨 張係数, 導電率などの物性值の異方性が小さいことを見出し ている ${ }^{9,10)}$ 。これは非常に興味ある現象であり，また実用上 重要な知見であるが，その詳細については明らかになってい ない。

そこで本研究では， $\mathrm{Cu}$ 母相中に $\mathrm{Cr}$ 相が圧延方向に一方 向に配列した $\mathrm{Cu}-15$ mass $\% \mathrm{Cr}$ 複相合金圧延材について圧延 方向 $(\mathrm{Cr}$ 相ファイバーの配列方向) から圧延横方向にわたる 様々な方位から引張試験片を採取し，それらの引張特性(ヤ ング率， $0.2 \%$ 耐力，UTS，伸び)を調べて，それらの異方 性について検討を行った。これらの試験を圧延まま材ならび に種々の温度で焼鈍した試料について行い，引張特性の異方 性とミクロ組織の変化について検討した。なお本研究では， ヤング率を引張試験で得られる応力ーひずみ曲線から求めた が，その後，横振動法を用いて精密測定し，集合組織の影響 も含めてさらに検討を行ったので，ヤング率の異方性に関し ては別報11)で述べることにする.

\section{2. 実 験 方 法}

\section{1 供試材}

本研究で用いた $\mathrm{Cu}-15$ mass $\% \mathrm{Cr}$ 合金圧延材は古河電気工 業株式会社メタル総合研究所提供の厚さ $0.3 \mathrm{~mm}$ の薄板で, 以下の方法で作製されたものである.

高周波真空溶解炬で溶製した合金鋳塊 $(\mathrm{Cu}$ マトリックス中 に初晶 $\mathrm{Cr}$ 相が分散した二相組織合金で化学組成は $14.85 \mathrm{Cu}$, $0.02 \mathrm{Al},<0.01 \mathrm{Fe},<0.01 \mathrm{P}$, bal. $\mathrm{Cu}(\operatorname{mass} \%))$ を面削後，熱間 圧延し, これを $\mathrm{Ar}$ 雲囲気中, $1273 \mathrm{~K}$ で $1 \mathrm{~h}$ 溶体化処理後, 水中に焼入れた。次に熱間圧延により破砕された $\mathrm{Cr}$ 相をフ アイバー状にするために冷間圧延を施した。冷間圧延は 1 パスの加工率が $10 \%$ 以下となるような条件で繰返し行い, 最終厚さ $0.3 \mathrm{~mm}$, 加工率 $99.1 \%$ の薄板に仕上げた.

\section{2 焼鈍処理}

Jin らは $\mathrm{Cu}-15$ mass $\% \mathrm{Cr}$ 合金線材について導電率を測定 し，導電率は焼鈍温度の上昇に伴い増加し， $773 \mathrm{~K} \sim 973 \mathrm{~K}$ で70\% IACS を越えることを報告している7). 本研究ではこ の結果をふまえ，後述する導電率測用試料には $473 \mathrm{~K}, 673$ $\mathrm{K}, 773 \mathrm{~K}, 873 \mathrm{~K}, 973 \mathrm{~K}, 1073 \mathrm{~K}$ の各温度で $1 \mathrm{~h}$ の焼鈍処理 を施した．また引張試験用試料については， $\mathrm{Cu}$ と $\mathrm{Cr}$ の再 結晶温度の違いを考慮し， $773 \mathrm{~K}-4$ h, $873 \mathrm{~K}-4 \mathrm{~h}, 1173 \mathrm{~K}-1$ hの 3 種類の焼鈍温度を選択した．熱処理は試験片を石英管 に真空封入し，これを電気师内に保持して行った。

\section{3 導電率測定}

Fig. 1 に示すように圧延方向に対し， $0^{\circ}, 45^{\circ}, 90^{\circ}$ の方向 から幅 $4.85 \mathrm{~mm}$, 長さ $80 \mathrm{~mm}$ の短冊状試験片を放電加工に より切り出した。ここで図中の細かい平行線は $\mathrm{Cr}$ 相ファイ バーの配列を模式的に表わしたものである。導電率測定は四 端子電位差法を用いて行った.ソースメータ (KEITHLEY 社製， Model 2400) にて一定印加電流 $100.00 \mathrm{~mA}$ を発生さ

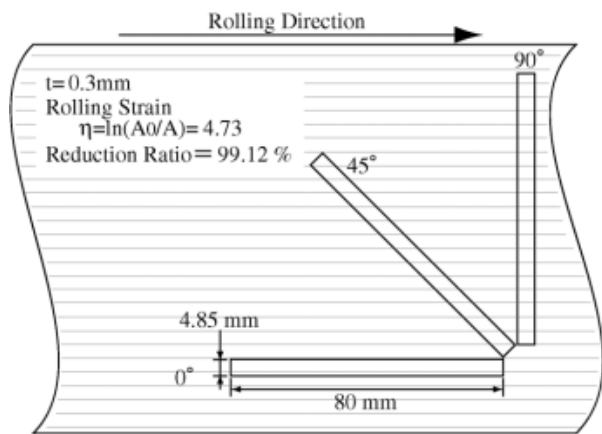

Fig. 1 Specimen orientation for electric conductivity measurement with respect to the rolling direction of the plate.

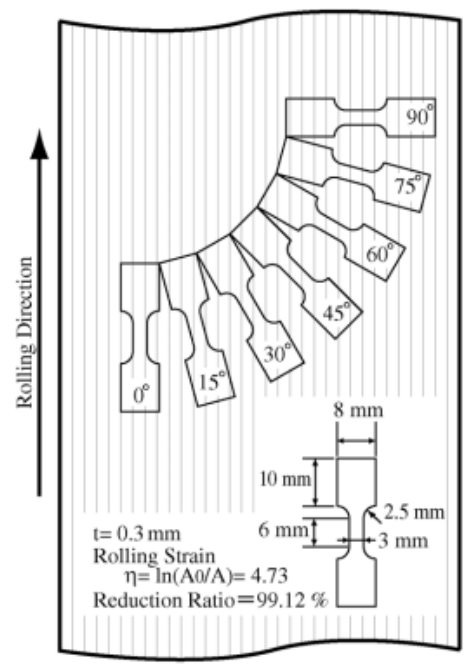

Fig. 2 Size and orientation of the tensile test specimen with respect to the rolling direction of the plate.

せ，端子間の電位差をナノボルトメータ(KEITHLEY 社製， Model 2182) で測定した. 定電流は一定周期で正負を反転さ せ，これにより熱起電力の影響を防止した。なお電圧端子間 の距離は長い方が精度よく測定できるため通常 100〜200 $\mathrm{mm}$ とするが，本研究では圧延材の圧延横方向の幅の制約か ら $62.5 \mathrm{~mm}$ とした. 得られた電圧值から比抵抗值を求め, これを導電率 $(\% \mathrm{IACS})$ に換算した。

\section{4 引張試験}

ゲージ長さ $6 \mathrm{~mm}$, ゲージ幅 $3 \mathrm{~mm}$ の肩付平板引張試験片 を Fig. 2 に示すように圧延方向に対し $0^{\circ} \sim 90^{\circ}$ まで $15^{\circ}$ 間隔 で切り出した。図中の細かい平行線は $\mathrm{Cr}$ 相ファイバーの配 列を模式的に表わしたものであり，これより引張軸とファイ バーの配列方向との関係が理解できる.

この他，比較のために $\mathrm{Cu}-15$ mass $\% \mathrm{Cr}$ 合金線材（直径約 $2.8 \mathrm{~mm}$, 冷間加工率は 99.1\%で圧延材と同じであり, 化学 組成は $14.8 \mathrm{Cu} ， 0.008 \mathrm{Fe} ，<0.001 \mathrm{Al} ，<0.001 \mathrm{Ca}$ ，bal. $\mathrm{Cu}$ $(\operatorname{mass} \%))$ を別途入手し，これをゲージ長さ $15 \mathrm{mm，ゲー}$ ジ部直径 $1.0 \mathrm{~mm}$ の肩付丸棒引張試験片に加工し，引張試験 に供した。

引張試験はインストロン型引張試験機 (NMB 製, TG-10 $\mathrm{kN})$ を用い，室温，大気中，ひずみ速度 $2.78 \times 10^{-4} \mathrm{~s}^{-1}$ で 
行った。ひずみはゲージ部に装着したひずみゲージを用いて 測定した. 力学的性質としてはヤング率, $0.2 \%$ 耐力, UTS, 破断伸びを求めた。

\section{5 組織観察}

$\mathrm{Cu}$ マトリックス中の $\mathrm{Cr}$ 相の配向は, 圧延材の縌断面, 横断面を研摩後，30\%の硝酸水溶液で $30 \mathrm{~s}$ 腐食し， Cu マト リックス相を軽く除去して得た組織を SEM (JEOL 製, JSM-5310) 観察して調べた. Cr 相ファイバーの形状は, 試 料を濃硝酸に浸し， $\mathrm{Cu}$ 相を除去して SEM により観察した。

$773 \mathrm{~K}$ で焼鈍した試料については，引張試験中，塑性ひず みが約 3\%となった時点で試験を中断し, 試験片表面を光学 顕微鏡により観察した.

引張破断材の破面観察ならびに破面上に見られた介在物 の分析を SEM ならびに付属の $\mathrm{EDX}(\mathrm{JEOL}$ 製, EX54010BE)により行った.

\section{3. 実 験 結 果}

\section{1 圧延材中の $\mathrm{Cr}$ 相ファイバーの配向と形状}

鋳造組織では初晶として晶出する $\mathrm{Cr}$ 相はデンドライト状 形態を有する単結晶であるが，これが熱間加工により分断さ れる。これが冷間圧延により圧延方向にファイバー状に延伸 し， $\mathrm{Cu}$ との複相組織を形成する。なお， $\mathrm{Cu}$ マトリックスに は共晶反応で生成する微細な針状 $\mathrm{Cr}$ 相も含まれている.

Fig. 3 (a)，(b) は圧延まま材の縦断面と横断面のミクロ組織 である。 $\mathrm{Cu}$ マトリックス中に短冊状の $\mathrm{Cr}$ ファイバーが密 に配列している。厚みは必ずしも均一ではなく，こぶのよう な部分もある。

Fig. 4 は Cr 相ファイバーの SEM 像である.これは濃硝 酸中でマトリックスから抜け落ちた $\mathrm{Cr}$ 相を集め, 観察した ものであり，これにより $\mathrm{Cr}$ 相ファイバーは極めて薄い平板 状であることがわかる． また Fig. 3 では Cr 相ファイバーは $\mathrm{Cu}$ マトリックス中では圧延方向に平行に直線状に伸びてい るが，ここでは彎曲している。これは $\mathrm{Cu}$ マトリックス中に おける $\mathrm{Cr}$ 相ファイバーの弾性変形や残留応力の存在を示唆 している. 以上の観察結果から $\mathrm{Cr}$ 相ファイバーの平均的な 形状は，厚さ $1 \mu \mathrm{m}$ 幅 $10 \mu \mathrm{m}$ で長さは数 $\mathrm{mm}$ である.

安達ら ${ }^{2)}$ はファイバー状 $\mathrm{Cr}$ 相の集合組織を調べ，冷間圧 延集合組織は板面垂直方向に $\langle 100\rangle$, 圧延方向に $\langle 110\rangle$ を平 行とする $(001)\langle 110\rangle$ の安定方位に集積することを明らかに している。また $\mathrm{Cu}$ マトリックスの冷間加工集合組織は純 $\mathrm{Cu}$ と同じく\{011\}/〈211〉抢よび $\{112\} /\langle 111\rangle$ に集積すると報 告している.なお, 本研究に抢いても圧延まま材ならびに各 焼鈍材について Schultz 法による集合組織解析を行ったが， この結果については特に複相材のヤング率の異方性に及ぼす 影響という観点から別報11)において示すことにする.

本研究では，導電率測定用試料については $473 \mathrm{~K} ， 673 \mathrm{~K}$, $773 \mathrm{~K}, 873 \mathrm{~K}, 973 \mathrm{~K}, 1073 \mathrm{~K}$ の各温度で $1 \mathrm{~h}$ の焼鈍処理，引 張試験用試料については, $773 \mathrm{~K}-4$ h, 873 K-4 h, 1173 K-1 h で焼鈍処理を行っているが， $1173 \mathrm{~K}-1 \mathrm{~h}$ 処理材において も $\mathrm{Cr}$ 相ファイバーの分断や粗大化は観察されず，形状はほ (a)
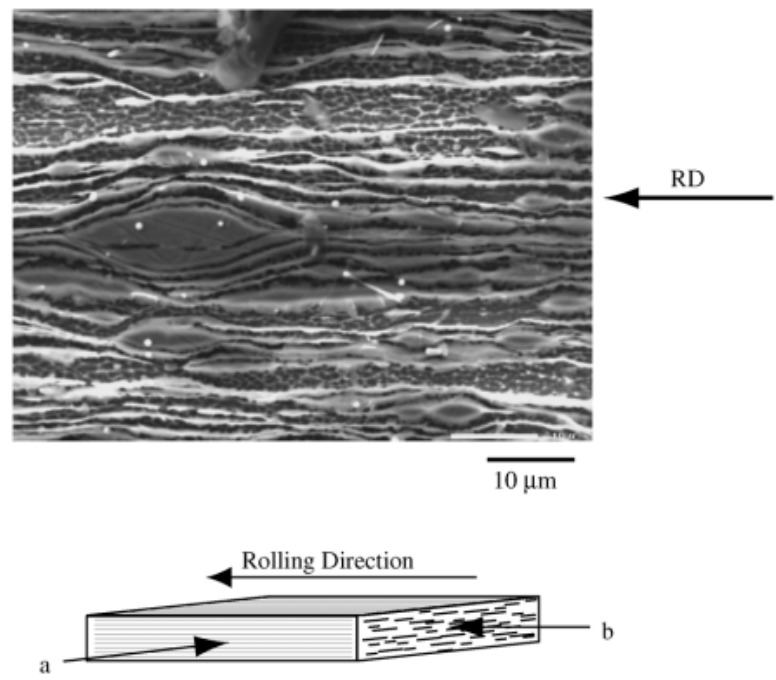

(b)

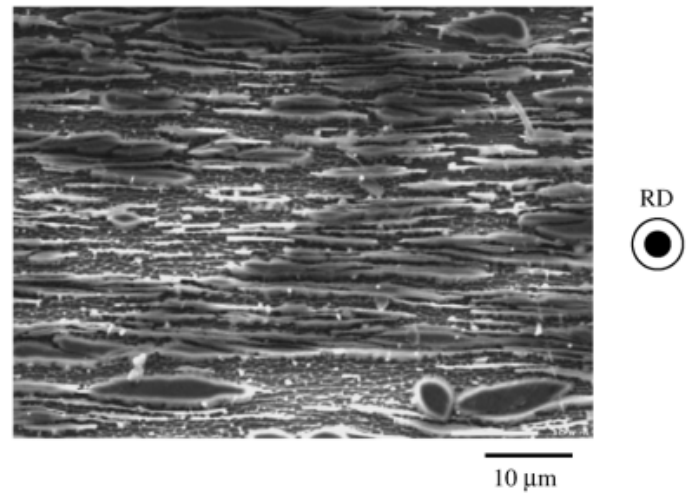

Fig. 3 Microstructure of the as-rolled $\mathrm{Cu}-15$ mass $\% \mathrm{Cr}$ composite. Cu matrix is etched selectively to reveal the embedded $\mathrm{Cr}$ fibers. (a) longitudinal section, (b) transverse section.

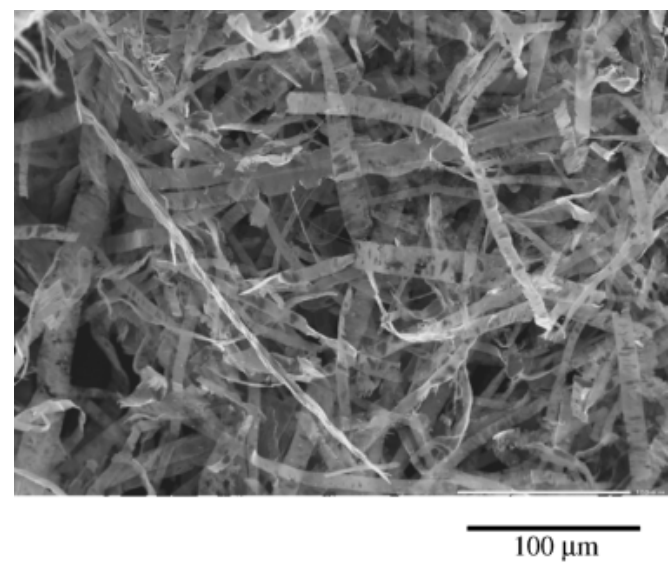

Fig. 4 Morphology of the $\mathrm{Cr}$ fibers in the cold-rolled $\mathrm{Cu}-15$ mass \% Cr composite. The composite was deeply etched using a nitric acid to remove the $\mathrm{Cu}$ matrix. The extracted $\mathrm{Cr}$ fibers were collected and observed under the SEM.

とんど変化していなかった

\section{2 導電率に及ぼすファイバー方位の影響}

Fig. 5 は 3 種類のファイバー方位(圧延方向に対し $0^{\circ}$, $\left.45^{\circ}, 90^{\circ}\right)$ について導電率の焼鈍温度による変化を示したも のである、いずれの方位に扔いても導電率は焼鈍温度ととも 


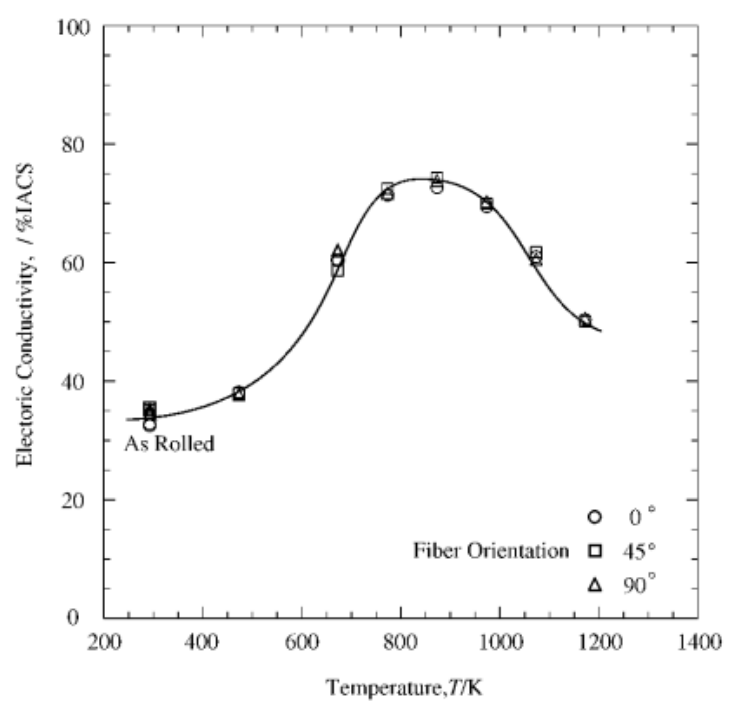

Fig. 5 Change in electric conductivity (\%IACS) with annealing temperature for the specimens of different fiber orientations.

に増加し， $773 \mathrm{~K} \sim 973 \mathrm{~K}$ でピークを示した後，減少してい る。このような導電率の焼鈍温度による変化は Jin ら7)が線 材について報告した結果とよく一致している，導電率の増加 は時効による $\mathrm{Cu}$ 相中の $\mathrm{Cr}$ の析出に対応している. $\mathrm{Cr}$ の析 出挙動に関しては, 時効初期には fcc 構造の $\mathrm{Cr}$ の微細析 出，ピークを示す温度範囲では整合ひずみを有する微細な bcc 構造の $\mathrm{Cr}$ 析出物に変化することが報告されている。ま たより高温での導電率の低下は析出物の再固溶によるもので ある7)。

いずれにしてもファイバー方位により導電率はほとんど変 化しないことが明らかであり, $\mathrm{Cu}$ マトリックス中の $\mathrm{Cr}$ の 析出状態のみに支配されることがわかった.

\section{$3.30 .2 \%$ 耐力ならびに UTS に及ぼす焼鈍温度ならびにフ ァイバー方位の影響}

Fig. 6 にファイバー方位 $0^{\circ}$ ，すなわち圧延方向に引張試 験を行った際の $0.2 \%$ 耐力, UTS 抢よび破断伸びの焼鈍温 度による変化を示す，焼鈍時間が異なっているため厳密な比 較はできないが，焼鈍温度の上昇とともに強度は低下し，延 性は増加している。

Fig. 7 は UTS とファイバー方位の関係に及ぼす焼鈍の影 響を示したものである。压延まま材のUTS は， $0^{\circ}$ から $45^{\circ}$ に向かって低下し，そこから $90^{\circ}$ に向かって増加して抢り， $45^{\circ}$ に谷をもつ $\mathrm{V}$ 字型を呈している. $45^{\circ}$ 方向の UTS は $0^{\circ}$ 方向の約 $75 \%$ である。 また $90^{\circ} の$ UTS は $0^{\circ}$ に比べやや小さ い，焼鈍温度の増加に伴い，いずれの方位に抢いてもUTS は低下するが，45での谷は徐々に浅くなり，1173 K 焼鈍材 の $45^{\circ}$ 方向の UTS は $0^{\circ}$ 方向の約 $90 \%$ となる.

Fig. 8 は $0.2 \%$ 耐力とファイバー方位の関係に及ぼす焼鈍 の影響を示したものである.UTSの場合と同様，圧延まま 材の耐力は $45^{\circ}$ に谷をもつ $\mathrm{V}$ 字型を呈している。また $90^{\circ}$ 方 向の耐力は $0^{\circ}$ 方向に比べ $60 \mathrm{MPa}$ ほど小さい. しかし，本 図に示すように，このような耐力の異方性は焼鈍によりほと

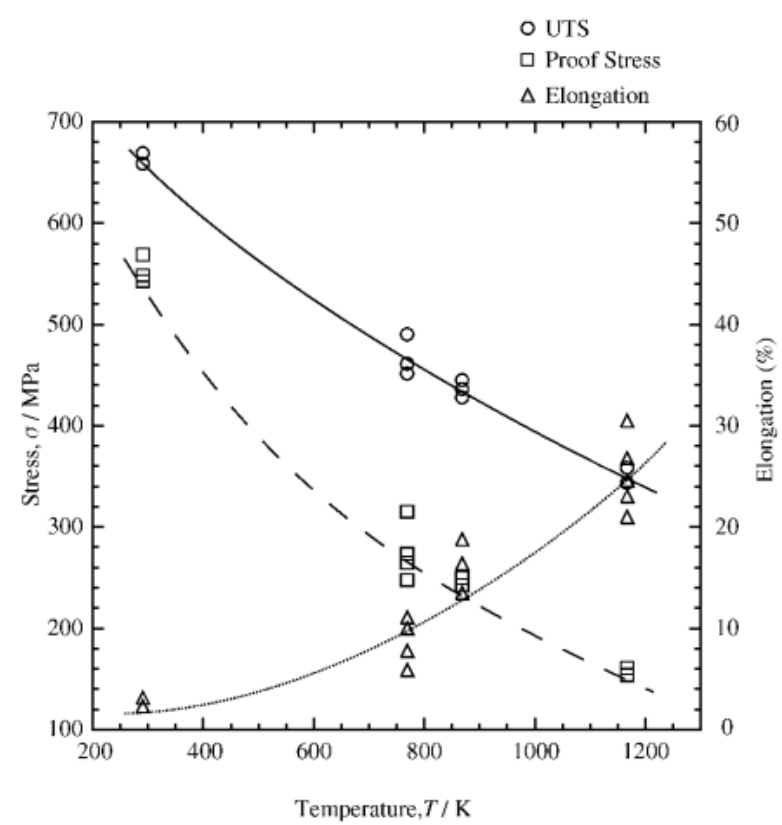

Fig. 6 Change in UTS, $0.2 \%$ proof stress and elongation with annealing temperature for the $0^{\circ}$ specimen.

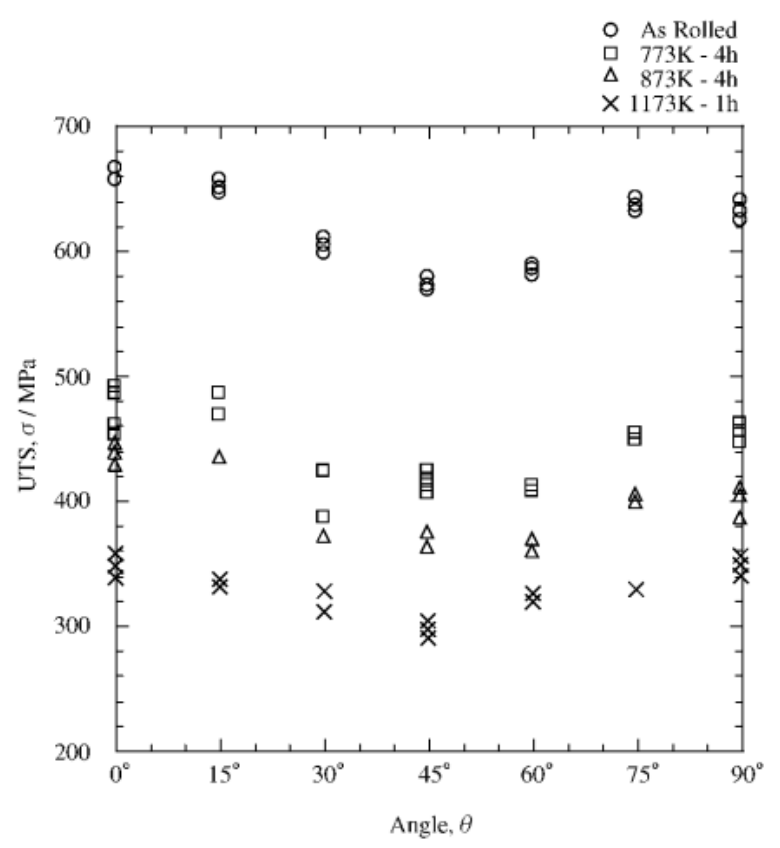

Fig. 7 Effects of fiber orientation and annealing condition on the UTS of the $\mathrm{Cu}-15$ mass $\% \mathrm{Cr}$ composite.

んど消失する.

\section{4 破断伸びに及ぼす焼鈍温度ならびにファイバー方位の 影響}

Fig. 9 に破断伸びとファイバー方位の関係に及ぼす焼鈍

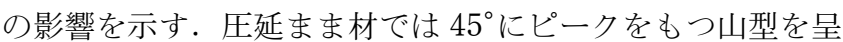
し，異方性が顕著であるが，焼鈍により $45^{\circ}$ 方向の山は急激 に低くなる，ただし伸びの絶対值は，焼鈍温度の増加ととも に低下し，压延まま材で $20 \sim 40 \%, 773 \mathrm{~K}-1 \mathrm{~h}$ 焼鈍材で 15 〜20\%であったものが， $1173 \mathrm{~K}-1 \mathrm{~h}$ 材では $2 \sim 6 \%$ にまで減 


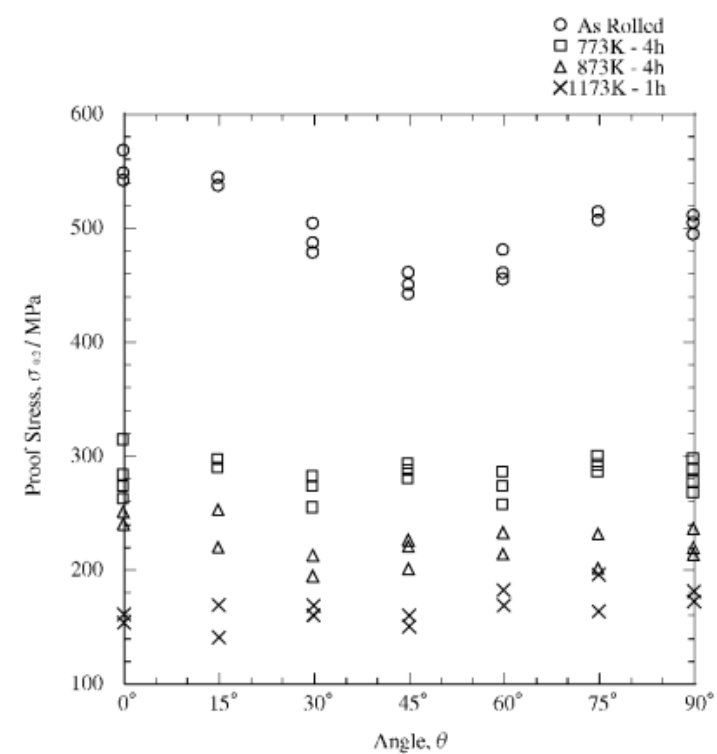

Fig. 8 Effects of fiber orientation and annealing condition on the $0.2 \%$ proof stress of the $\mathrm{Cu}-15$ mass $\% \mathrm{Cr}$ composite.

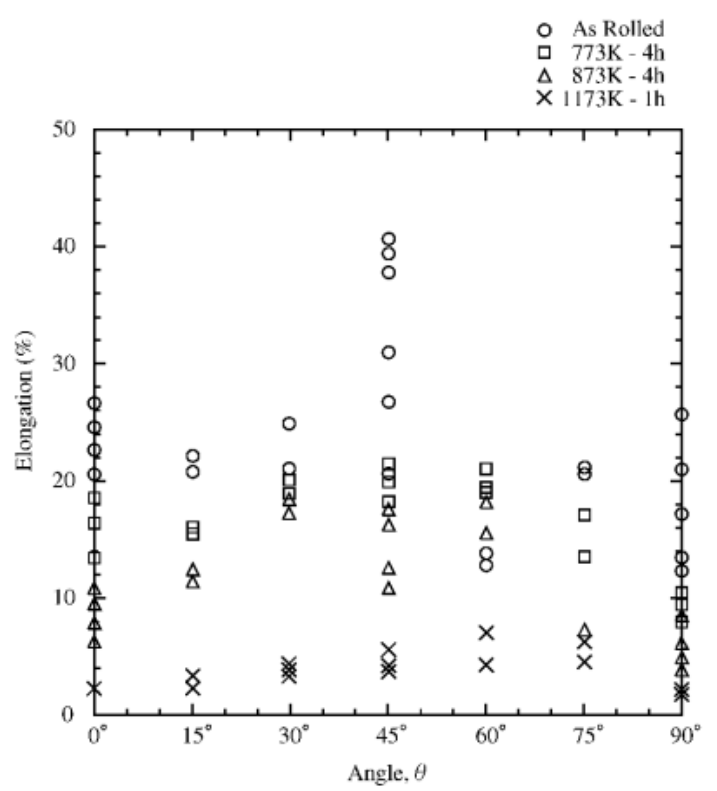

Fig. 9 Effects of fiber orientation and annealing condition on the elongation of the $\mathrm{Cu}-15$ mass $\% \mathrm{Cr}$ composite.

少している.

\section{5 ヤング率に及ぼす焼鈍温度ならびにファイバー方位の 影響}

Fig. 10 はヤング率とファイバー方位の関係に及ぼす焼鈍 の影響を示したものである. 圧延まま材では $45^{\circ} に$ に谷をもつ $\mathrm{V}$ 字型を呈している。 また $0^{\circ}$ に比べ $90^{\circ}$ のヤング率が大き い。亦た焼鈍材では方位による差が小さくなっている，ただ し，ここでのヤング率は引張試験で得られた応力ーひずみ曲 線の直線部の勾配功求めたものであり，焼鈍材では比較的 低荷重領域から直線からのずれが見られることなぞから，測 定方法に起因する誤差が含まれている可能性がある。よって Fig. 10 には，ヤング率の方位依存性に関する有益な情報が (a)

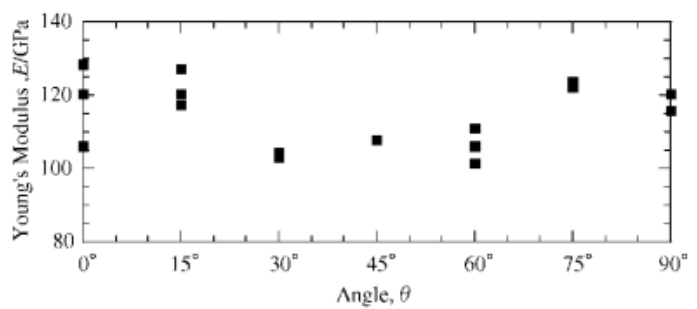

(b)

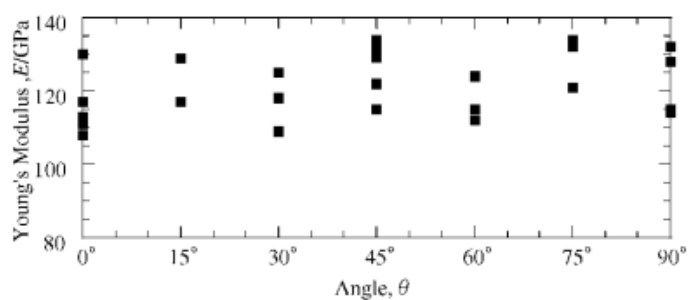

(c)

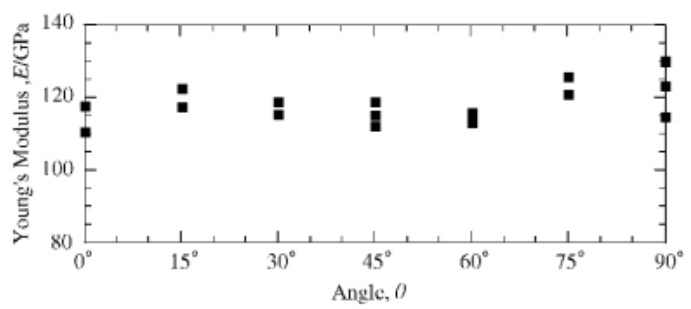

(d)

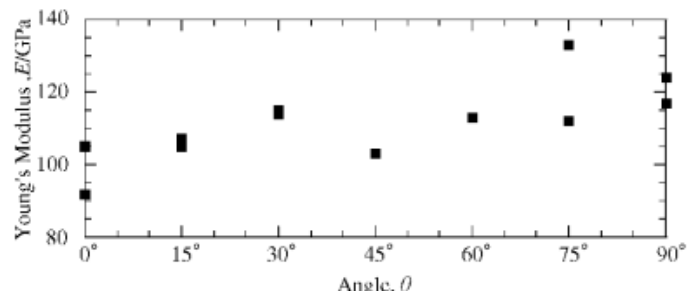

Fig. 10 Effects of fiber orientation and annealing condition on the Young's modulus of the $\mathrm{Cu}-15$ mass $\% \mathrm{Cr}$ composite.

(a) as rolled, (b) $773 \mathrm{~K}-4 \mathrm{~h}$, (c) $873 \mathrm{~K}-4 \mathrm{~h}$, (d) $1173 \mathrm{~K}-1 \mathrm{~h}$. The Young's modulus was obtained from the tensile stressstrain curve.

示されているものの，その絶対値について議論するには，よ り厳密な測定結果が必要であると考えられる。そこでヤング 率に関してはさらに横振動共振法を用いて, より詳細な測定 を行った。なお，横振動共振法による測定結果を含め，本複 相材のヤング率の異方性とその原因については別報11)で詳 しい検討を行っているので，ここでは割愛する。

\section{6 引張試験片の表面様相変化に及ぼすファイバー方位の 影響}

Fig. 11 は $773 \mathrm{~K}-4 \mathrm{~h}$ 焼鈍材に約 3\%の塑性ひずみを与 え, その後除荷して得られた引張試験片表面ゲージ部の光学 顕微鏡写真である. Fig. 11(a) は荷重軸に対しファイバー方 位が $0^{\circ}$ のもので, 予鏡面仕上げした試験片表面は, 細か く波をうった様相へと変化している．ファイバー方位が $30^{\circ}$ までは同様な表面組織变化が観察されたが，45以上にな ると試験片表面の凹凸が激しくなり，例えば $60^{\circ}$ 材では Fig. 11 (b)に示すような組織となる。これは引張軸に対しファイ バー方位が平行に近い場合には，せん断応力が最大となる 
(a)

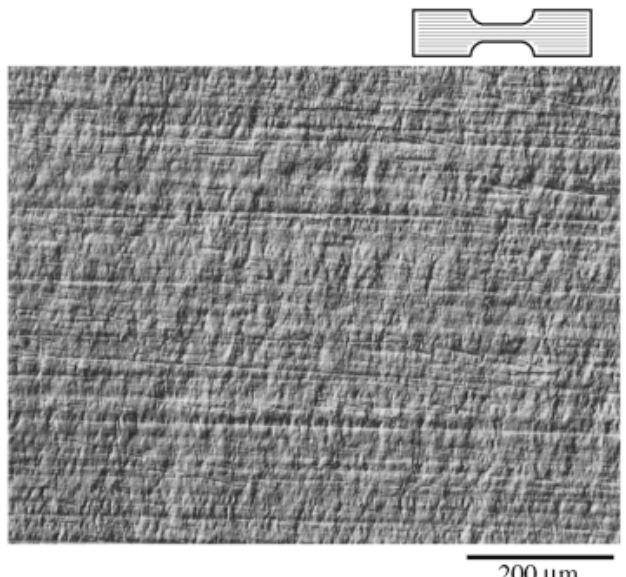

(b)

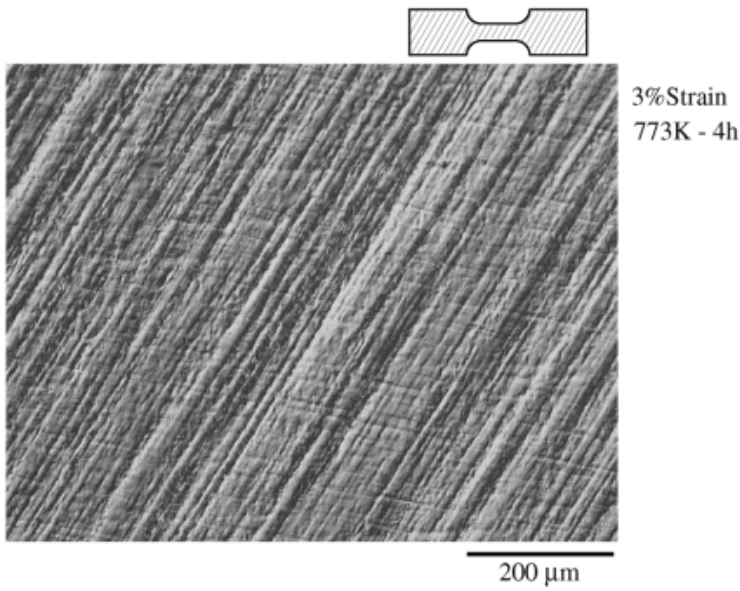

Fig. 11 Effects of fiber orientation on the surface morphology of the tensile specimen $(773 \mathrm{~K}-4 \mathrm{~h}$ annealed). The tensile test was interrupted at about $3 \%$ plastic strain and the surface of the gage section was observed using the SEM. (a) $0^{\circ}$, (b) $60^{\circ}$.

$45^{\circ}$ 方向のすべりが Crファイバーによって妨害され，その ため細かいすべりが多く発生して塑性変形を担うが，ファイ バー方向が $45^{\circ}$ に近い場合には，Cuマトリックスに大きな すべり帯が形成されやすくなり，そのため巨視的な凹凸が顕 著な表面が形成されるためであると考えられる。

\section{7 引張破断面様相に及ぼすファイバー方位の影響}

Fig. 12(a)〜 (c) は圧延まま材の引張破断面様相をファイ バー方位 $0^{\circ}, 45^{\circ}, 90^{\circ}$ について示した SEM 写真である。い ずれの破面も $\mathrm{Cu}$ マトリックス中の微細なディンプル組織と $\mathrm{Cr}$ 相ファイバーに起因する粗大なボイドから構成されてい る.ファイバー方位によりボイドの形状が大きく異なること がわかる，すなわち，00では長軸が $10 \mu \mathrm{m}$ 程度であり，こ れはほぼ $\mathrm{Cr}$ ファイバーの幅に一致する．破面上のボイドの 長さ (長軸) は $45^{\circ}$ で平均 $30 \mu \mathrm{m}, 90^{\circ}$ では写真の視野に納まら ないほどの長さになる。

破断した $\mathrm{Cr}$ ファイバーの断片は，破面近傍には見られ ず，ボイド底部を詳しく観察してはじめて観察可能であっ た。 たた，破面には，この他，直径が $5 \sim 10 \mu \mathrm{m}$ の等軸ディ ンプルが観察されるが，これについては次節で述べる. (a)

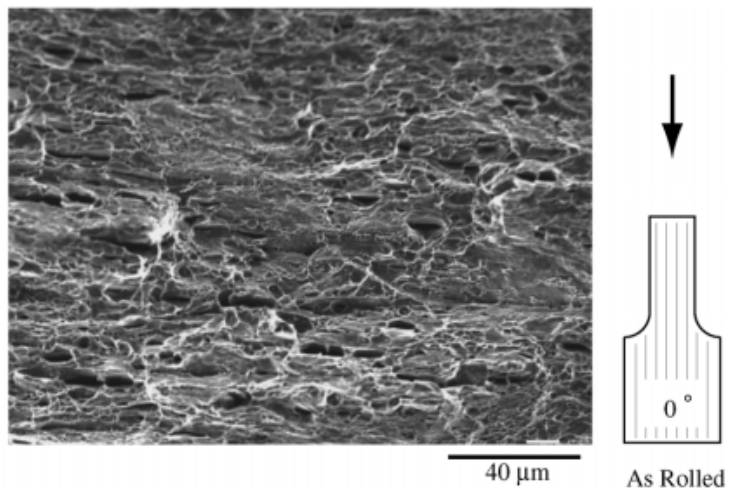

(b)

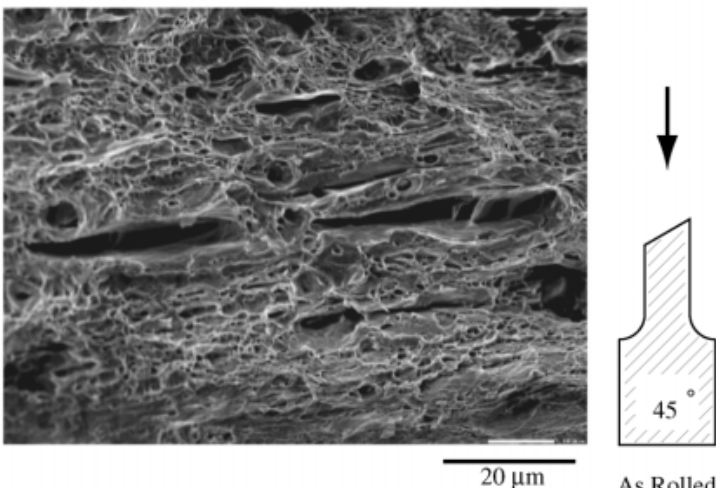

(c)

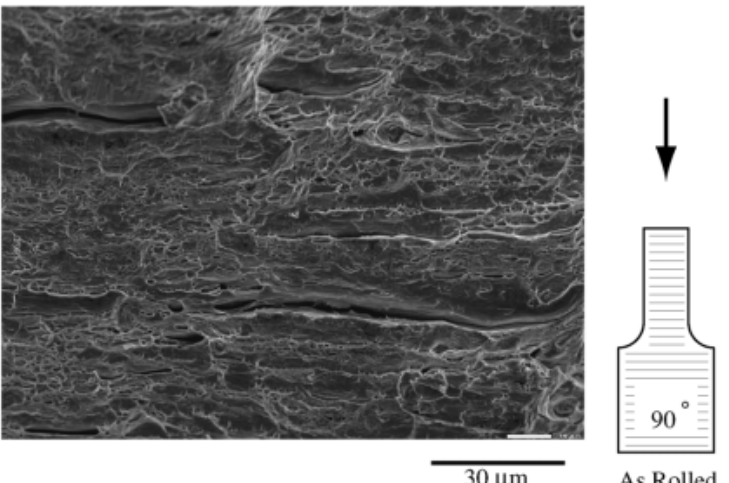

Fig. 12 Effects of fiber orientation on tensile fracture surface of the as-rolled specimen. (a) $0^{\circ}$, (b) $45^{\circ}$, (c) $90^{\circ}$.

\section{8 引張破断面様相に及ぼす焼鈍の影響}

Fig. 13(a)〜 (c) は各々ファイバー方位 $45^{\circ}$ の試料の圧延ま ま材， $773 \mathrm{~K}-4 \mathrm{~h}$ 焼鈍材， $1173 \mathrm{~K}-1 \mathrm{~h}$ 焼鈍材の引張破断面 様相である．焼鈍材では $\mathrm{Cu}$ マトリックスの微細なディンプ ルが深くなり，また Crファイバーに起因するボイドが観察 しにくくなる．これは $\mathrm{Cr}$ ファイバーの破断後も $\mathrm{Cu}$ マトリ ックスは十分塑性変形するため, ボイドの形状が扁平化した ためであると考えられる。ささて ボイドが目立たなくなる 分, 先に述べた直径 5 10 $\mu \mathrm{m}$ の等軸ディンプルが顕著に観 察されるようになる.さらにディンプルの底には Fig. 14(a) に示すような立方体形状の異物が観察された。 SEM-EDX を用いてこの異物の組成を分析したところ Fig. 14（b)に示 すように $\mathrm{Al}$ と $\mathrm{Cr}$ の強度が強いことが明らかとなった。こ の異物は焼鈍材に特有なものではなく, 圧延まま材にも観察 された。よってこれらは合金鋳塊の製造段階で既に存在して 
(a)

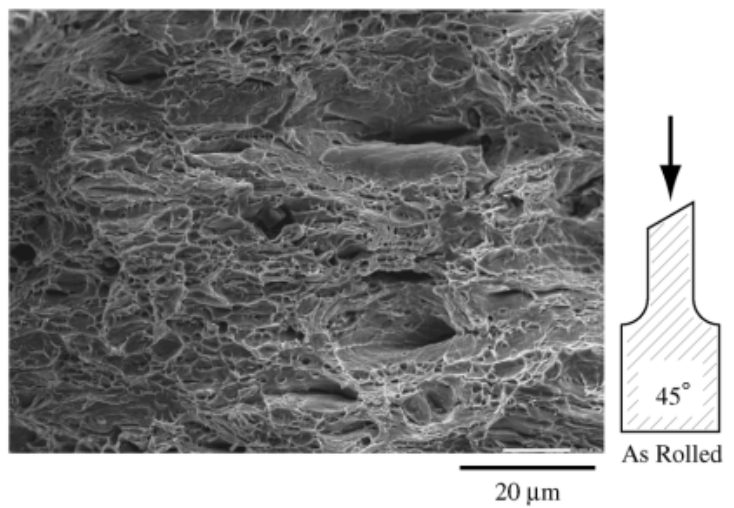

(b)

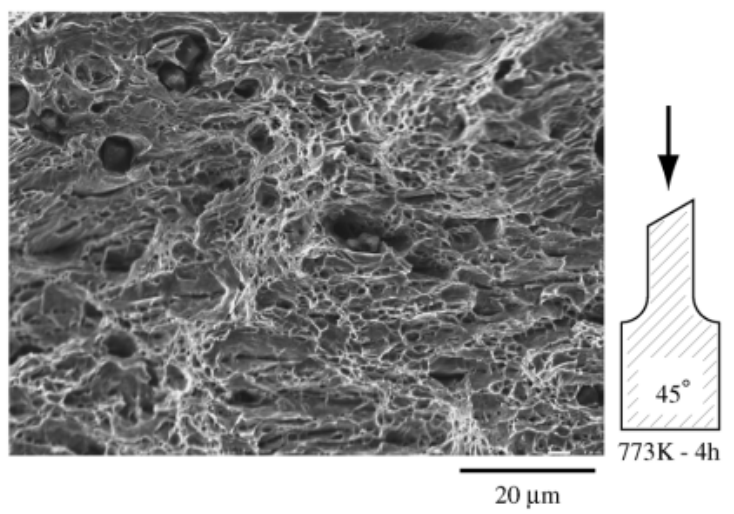

(c)

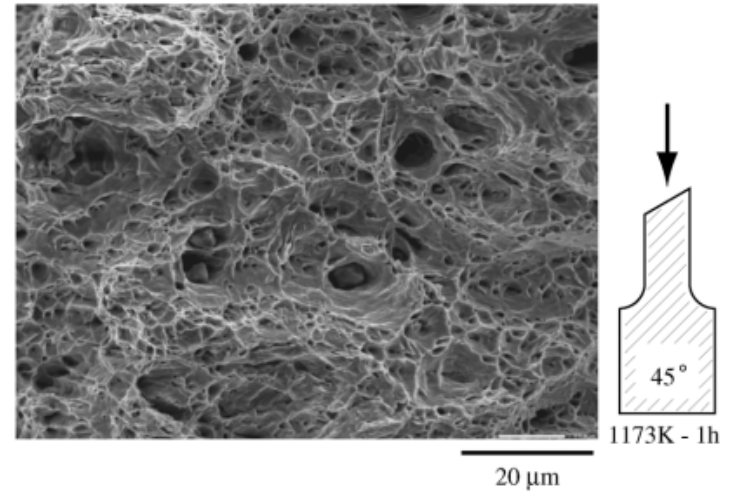

Fig. 13 Effects of the annealing treatment on tensile fracture surface of the $45^{\circ}$ specimen. (a) as rolled, (b) $773 \mathrm{~K}-4 \mathrm{~h}$, (c) $1173 \mathrm{~K}-1 \mathrm{~h}$.

いたと考えられる.

\section{4. 考察}

\section{1 複相合金圧延材の引張強度の異方性}

ここでは本研究で得られた $0.2 \%$ 耐力ならびにUTS の方 位依存性について検討を行う。本複相合金圧延材は一種の in situ 型の一方向ファイバー強化複合材料と見なすことが できる. 一方向ファイバー強化複合材料破壊強度とその異方 性については従来, 最大応力説による検討が行われている. これは主応力が臨界応力に達したにときに破壊が起こるとす るもので，3つの破壊様式に対応した臨界条件が考えられる.

$$
\begin{aligned}
& \sigma_{0}=\sigma_{0}^{*} \\
& \sigma_{90}=\sigma_{90}^{*} \\
& \tau_{0}=\tau_{0}^{*}
\end{aligned}
$$

(a)

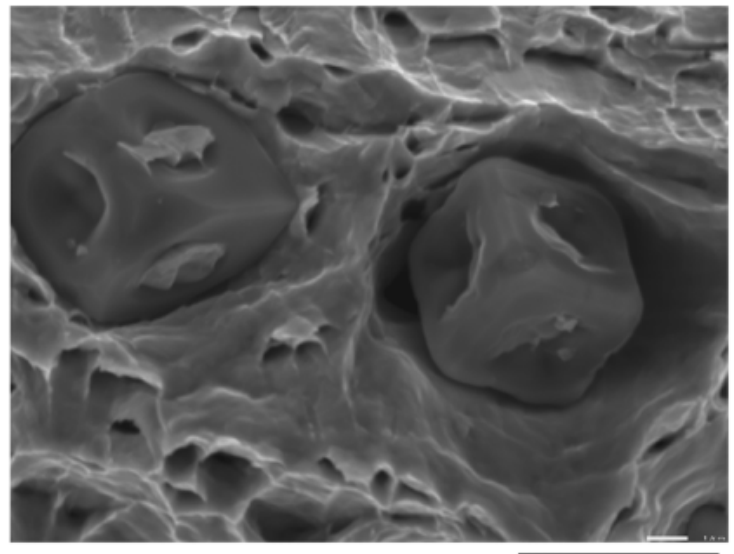

$5 \mu \mathrm{m}$

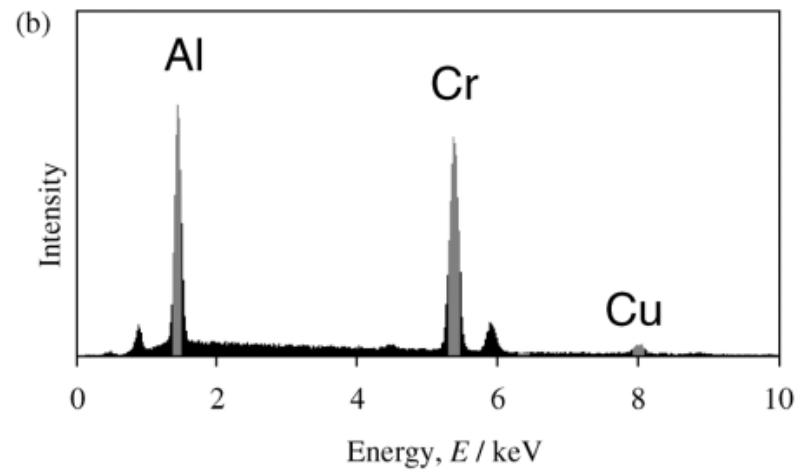

Fig. 14 The SEM image of the cubic inclusion located at the depth of the dimple, (a) and the EDX analysis of the inclusion.

これらと負荷応力 $\sigma_{\theta}$ との関係は次式で表される.

$$
\begin{aligned}
& \sigma_{0}=\sigma_{\theta} \cos ^{2} \theta \\
& \sigma_{90}=\sigma_{\theta} \sin ^{2} \theta \\
& \tau_{0}=-\sigma_{\theta} \sin \theta \cos \theta
\end{aligned}
$$

よって, 中間の角度(方位)に拈破壊強度 $\sigma_{\theta}$ は次の応力 のうち最小となるもので決まる.

$$
\begin{aligned}
& \sigma_{\theta}=\sigma_{0}^{*} / \cos ^{2} \theta \\
& \sigma_{\theta}=\sigma_{90}^{*} / \sin ^{2} \theta \\
& \sigma_{\theta}=\tau_{0}^{*} / \sin \theta \cos \theta
\end{aligned}
$$

Hill は等方等質物体に関する von Mises の破壊条件を非等 方物質に拡張し, その後 Tsai はさらに修正を加え, 複合材 料への適用を可能にした。これが Tsai-Hill 則として知られ る複合材料の破壊条件であり, 次式で表される12).

$$
\left(\frac{\sigma_{0}}{\sigma_{0}^{*}}\right)^{2}-\left(\frac{\sigma_{0} \sigma_{90}}{\sigma_{0}^{* 2}}\right)+\left(\frac{\sigma_{90}}{\sigma_{90}^{*}}\right)^{2}+\left(\frac{\tau_{0}}{\tau_{0}^{*}}\right)^{2}=1
$$

式 (3)の関係を用いて, 式 (4)を書き換えると破壊応力の 方位依存性は以下のように書ける。

$$
\sigma_{\theta}=\left[\frac{\cos ^{4} \theta}{\sigma_{0}^{* 2}}+\left(\frac{1}{\tau_{0}^{* 2}}-\frac{1}{\sigma_{0}^{* 2}}\right) \sin ^{2} \theta \cos ^{2} \theta+\frac{\sin ^{4} \theta}{\sigma_{90}^{* 2}}\right]^{-1 / 2}
$$

Thai-Hill 則は弾性体の破壊をよく記述できることが知ら れている. 本複合材料の構成金属である $\mathrm{Cu}, \mathrm{Cr}$ はともに塑 性変形するため, Thai-Hill 則がそのまま適用できるという 理論的根拠はないが，Thai-Hill 則で本複相合金圧延材の引 張強度の異方性が記述できるかどうか調べることは意義があ る，そこで，本複相合金圧延材の圧延まま材について，塑性 


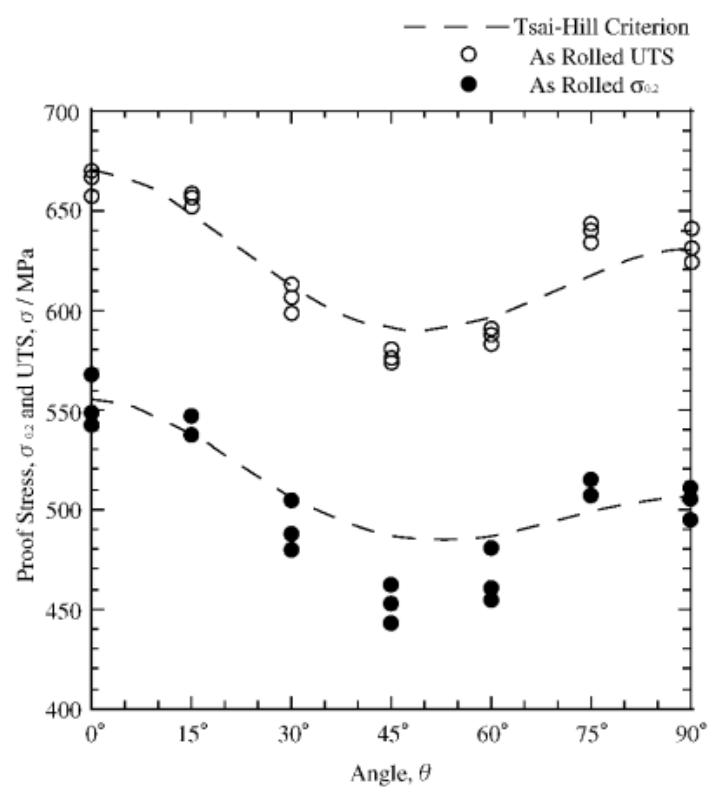

Fig. 15 Orientation dependence of fracture strength predicted by Tsai-Hill criterion. Plotted data points are experimentally obtained $0.2 \%$ proof stress and UTS values in the present study.

変形の影響がごく僅かであると考えられる $0.2 \%$ 耐力ならび に弾性体の破壊応力に対応すると考えられる UTSの方位依 存性を求めた。本複相合金圧延材の $0.2 \%$ 耐力, UTS につ いて $0^{\circ}$ を $\sigma_{0}^{*}, 90^{\circ}$ を $\sigma_{90}^{*}, \tau_{0}^{*}$ を $(1 / 2) \sigma_{0}^{*}$ として，各々式(5)に 代入すると $\sigma_{\theta}$ は Fig. 15 中の曲線となり, 実験で求めた $0.2 \%$ 耐力ならびにUTS の方位依存性の結果と非常によく 一致する．このように本複相合金圧延材の引張強度の方位依 存性は Tsai-Hill 則によって表すことができることがわかっ た。

\section{2 本合金中に観察された異物の起源と複相材の伸びに及 ぼす影響}

Fig. 12(a)〜 (c)に示したように，本複相材の引張破断面 には $\mathrm{Cu}$ マトリックス中の微細なディンプル組織と $\mathrm{Cr}$ 相フ アイバーに起因する粗大なボイドの他，直径が $5 \sim 10 \mu \mathrm{m}$ の 等軸ディンプルが観察された。このディンプルの底には Fig. 14 (a) に示すような立方体形状の異物が観察され， SEM-EDX 分析により $\mathrm{Al}$ と $\mathrm{Cr}$ の強度が強いことが明らか となった。この異物は圧延まま材にも観察されることから， 合金鋳塊の製造段階で既に存在していたと考えられる.

供試材の化学組成を見ると， 0.02 mass\%の $\mathrm{Al}$ が含まれて おり，抢そらく溶解・鋳造の過程で耐火物等から不純物成分 として $\mathrm{Al}$ が混入し，その結果， $\mathrm{Al}-\mathrm{Cr}$ 系の晶出相が生じ, $\mathrm{Cu}-\mathrm{Cr}$ 合金溶湯中に分散したものと推測される．先に述べ たように本圧延材の導電率は $\mathrm{Al}$ を不純物として含んでいな い線材の導電率と変わらない。従って， $\mathrm{Al}$ は $\mathrm{Cu}$ マトリッ クス中に固溶しているのではなく， $\mathrm{Al}-\mathrm{Cr}$ 系の晶出相形成に 費やされたものと考えられる.

さて，試料の任意の断面を観察した結果，この立方体の異 物は破断面には多く観察されるが，試料中には僅かしか含ま
れていないことがわかった。このことは，特に焼鈍材におい ては，この異物が破断の起点となったことを示すものであ る.よって，もし本合金製造に用いられた溶湯がより清浄で あったならば，さらに大きな延びが得られたものと推測でき る.

\section{5. 結 論}

$\mathrm{Cu}$ 母相中に $\mathrm{Cr}$ 相ファイバーが圧延方向に一方向に配列 した $\mathrm{Cu}-15$ mass \% Cr 複相合金圧延材に関し，圧延方向 $(\mathrm{Cr}$ 相ファイバーの配列方向) から圧延横方向にわたる様々な方 位について引張特性を調べ，その異方性について調べた。さ らに引張特性の異方性ならびに引張破断組織に及ぼす焼鈍の 影響について検討を行った，その結果，本圧延材では第 2 相 が圧延方向に配向しているにもかかわらず，導電率はもとよ り引張特性の異方性が比較的小さく，また焼鈍によりさらに 減少することが明らかとなった。本研究で得られた知見を以 下に示す.

（1）いずれのファイバー方位においても $0.2 \%$ 耐力，UTS は焼鈍温度の上昇とともに低下し，延性は増加した。

（2）圧延まま材の UTS のファイバー方位依存性は， $45^{\circ}$ に谷をもつ $\mathrm{V}$ 字型を呈し， $45^{\circ}$ 方向の UTS は $0^{\circ}$ 方向の約 $75 \%$ であった。焼鈍温度の増加に伴い，いずれの方位にお いても UTS は低下するが，45の谷は徐々に浅くなり， $1173 \mathrm{~K}$ 焼鈍材の $45^{\circ}$ 方向の UTS は $0^{\circ}$ 方向の約 $90 \%$ であっ た。

（3）UTSのファイバー方位依存性を複合材料の破壊条件 である Tsai-Hill 則と比較検討したところ，よく一致するこ とがわかった。

（4） $0.2 \%$ 耐力も UTS の場合と同様，圧延まま材の耐力 は $45^{\circ}$ に谷をもつ V 字型を呈したが，焼鈍によりファイバー 方位による差はほとんど見られなくなった。

（5）引張破断面は $\mathrm{Cu}$ マトリックス中の微細なディンプル 組織と $\mathrm{Cr}$ 相ファイバーに起因する粗大なボイドから構成さ れており，後者のボイド形状はファイバー方位により異なっ ていた．焼鈍材では $\mathrm{Cu}$ マトリックスの微細なディンプルは 深く，また Crファイバーに起因するボイドが観察しにくか った.これは焼鈍材では $\mathrm{Cr}$ ファイバーの破断後も $\mathrm{Cu}$ マト リックスが十分塑性変形するため, ボイド形状が扁平化した ためであると考えられる.

（6）導電率はファイバー方位に依存しなかった，導電率は 焼鈍温度とともに増加し， $773 \mathrm{~K} \sim 973 \mathrm{~K}$ でピークを示した 後, 減少した。焼鈍により $\mathrm{Cr}$ 相ファイバーの形状はほとん ぞ変化しないことから導電率は $\mathrm{Cu}$ マトリックス中の $\mathrm{Cr}$ の 析出状態のみに支配されていると考えられる.

本研究の一部は新エネルギー・産業技術総合開発機構の新 規産業創造型提案公募事業に対する支援によって行われた. 記して謝意を表する．本研究を遂行するにあたり有益なご議 論, ご助言をいただいた元金属材料技術研究所 鈴木洋夫博 土, 古河電気工業侏 大山好正博士, 三原邦照博士に感謝の 意を表する。 
文献

1) H. G. Suzuki and K. Mihara: Materia Japan 38(1998) 714-712.

2) K. Adachi, S. Tsubokawa, T. Takeuchi and H. G. Suzuki: J. Japan Inst. Metals 61 (1997) 391-396.

3) K. Adachi, S. Tsubokawa, T. Takeuchi and H. G. Suzuki: J. Japan Inst. Metals 61 (1997) 397-403.

4) K. Mihara, T. Takeuchi and H. G. Suzuki: J. Japan Inst. Metals 61(1997) 1044-1049.

5) K. Mihara, T. Takeuchi and H. G. Suzuki: J. Japan Inst. Metals 62(1998) 238-245.

6) K. Mihara, T. Takeuchi and H. G. Suzuki: J. Japan Inst. Metals
62(1998) 599-606.

7) Y. Jin, K. Adachi, T. Takeuchi and H. G. Suzuki: Metall. Mater. Trans. A 29A (1998) 2195-2203.

8) D. L. Zhang, K. Mihara, E. Takakura and H. G. Suzuki: Mater. Sci. Eng. A226 (1999) 99-108.

9) K. Mihara, M. Kurihara, Y. Oyama and H. G. Suzuki: Furukawa Electric Annual Report 107 (2001) 53-57.

10) K. Mihara, Y. Oyama and H. G. Suzuki: J. JCBRA 36(2000) $227-232$.

11) S. Kumai, G. Wakana S. Onaka, M. Kato and A. Sato: J. Japan Inst. Metals. 67 (2003) 324-330.

12) D. Hull: An introduction to composite materials, (Cambridge University Press, Cambridge, 1981) pp. 164-173. 